\title{
Burkitt-Like Lymphoma with 11q Aberration
}

National Cancer Institute

\section{Source}

National Cancer Institute. Burkitt-Like Lymphoma with 11 q Aberration. NCI Thesaurus.

Code C131911.

A molecularly distinct B-cell lymphoma reminiscent of Burkitt lymphoma. It is characterized by the absence of MYC translocation and the presence of chromosome $11 q$ aberrations. 